\title{
Stable and noble gas isotopic study of thermal and groundwaters in northwestern Hokkaido, Japan and the occurrence of geopressured fluids
}

\author{
AKIRA Ueda, ${ }^{1 *}$ KeIsUKe Nagao, ${ }^{2}$ Tomo Shibata $^{3}$ and TaKahiro SuZUKI ${ }^{3}$ \\ ${ }^{1}$ Department of Civil and Earth Resources Engineering, Graduate School of Engineering, Kyoto University, \\ C1-2-155, Katsura, Nishikyo-ku, Kyoto 616-8540, Japan \\ ${ }^{2}$ Laboratory for Earthquake Chemistry, Graduate School of Science, The University of Tokyo, \\ 7-3-1, Hongo, Bunkyo-ku, Tokyo 113-0033, Japan \\ ${ }^{3}$ Geological Survey of Hokkaido, Kita-19 Nishi-12, Kita-ku, Sapporo, Hokkaido 060-0819, Japan
}

(Received July 14, 2009; Accepted June 7, 2010)

\begin{abstract}
Thermal and groundwaters are distributed along the west coast and in the inland region of Northwestern Hokkaido, Japan. The waters in the latter group have relatively high temperatures. Stable (D, O) and noble gas isotopic compositions of 23 thermal and groundwaters were analyzed to investigate their origins. The $\mathrm{Cl}$ concentrations vary from 45 to 19,300 $\mathrm{mg} / \mathrm{L}$ and the $\delta \mathrm{D}$ values are in the range of -90 to $-8 \%$. The $\delta \mathrm{D}-\delta^{18} \mathrm{O}$ plots show a linear relationship which can be explained by a simple mixing of local meteoric waters and altered sea water, with oxygen isotopic shift of 5\%o. However, a $\delta \mathrm{D}-\mathrm{Cl}$ plot shows that there is also a contribution of an additional water component of different origin. This 3rd component has a $\delta \mathrm{D}$ value of $-20 \%$ and $\mathrm{Cl}$ concentration of $6,000 \mathrm{mg} / \mathrm{L}$. Multivariate statistical analysis of the observed chemical and isotopic compositions using the code M3 (M; multivariate mixing and mass balance) also supports the view that the Toyotomi thermal water has the composition closest to that of the 3rd groundwater component. This component is regarded as a geopressured fluid.

The ${ }^{3} \mathrm{He} /{ }^{4} \mathrm{He}$ ratios in these waters are in the range of $(0.1-5) \times 10^{-6}$, which indicate contributions of both mantle and crustal He to the thermal and groundwaters in the studied area. The Toyotomi thermal water has a ${ }^{3} \mathrm{He} /{ }^{4} \mathrm{He}$ ratio of $5.5 \times$ $10^{-7}$, and a high ${ }^{3} \mathrm{He} /{ }^{20} \mathrm{Ne}$ ratio $(\sim 700)$. These results indicate a crustal He input with a small amount of mantle-derived He and imply that the 3 rd groundwater component is of deep origin. On the basis of isotopic and chemical compositions, 5 of 23 samples studied groundwater and thermal waters are contributed by a geopressured fluid component. The results show that geopressured fluids with a $\delta \mathrm{D}$ value of $-20 \%$ and $\mathrm{Cl}$ concentration of $6,000 \mathrm{mg} / \mathrm{L}$ are widely distributed in northwestern Hokkaido.
\end{abstract}

Keywords: geopressured fluid, hydrogen isotope, oxygen isotope, helium isotope, Hokkaido

\section{INTRODUCTION}

One of Professor Hitoshi Sakai's contributions to earth sciences was the identification of several groups of thermal waters in Japan, based on their isotopic and chemical compositions. He employed isotopic data to constrain the origin of Arima and coastal type waters (Sakai and Matsubaya, 1974, 1976) and also applied these data to interpret the origins and evolution of Kuroko ore forming fluids (Hattori and Sakai, 1979). In these papers, it was also recognized that the isotopic composition of fossil sea water differed from that of the original sea water

\footnotetext{
*Corresponding author (e-mail: akira@sci.u-toyama.ac.jp)

*Presnet address: Graduate School of Science and Engineering, University of Toyama, 3190 Gohuku, Toyama 930-8555, Japan.
}

Copyright $\odot 2010$ by The Geochemical Society of Japan. owing to interaction with the surrounding rocks. In several areas, fossil sea water was found to have $\delta^{18} \mathrm{O}$ values of +5 to $+8 \%$ o due to the oxygen isotopic shift caused by the interaction, but to retain almost the same $\mathrm{Cl}$ concentration as fresh sea water (e.g., Sakai and Matsubaya, 1974; Mizukami et al., 1977; Shibata et al., 2005).

At depths below $c a .2 \mathrm{~km}$ in sedimentary regions associated with oil and/or natural gas, formation waters tend to be geopressured fluid with pressures between hydrostatic and lithostatic values (e.g., Myers, 1968; Jones, 1970; Oki et al., 1999; Xu et al., 2006). The $\delta \mathrm{D}$ and $\delta^{18} \mathrm{O}$ data show that most geopressured fluid can be explained as a mixture of fossil sea water and local meteoric water, with an oxygen isotope shift due to rock-water interaction. Recently, fluids that have oilfield-like characteristic, with unusually high $\delta \mathrm{D}(-20 \%)$ and low $\mathrm{Cl}$ concentrations $(c a .6,000 \mathrm{mg} / \mathrm{L})$ have been observed along faults in the Horonobe area (Ishii et al., 2006). These fluids might have originated as a mixture between sea water and 


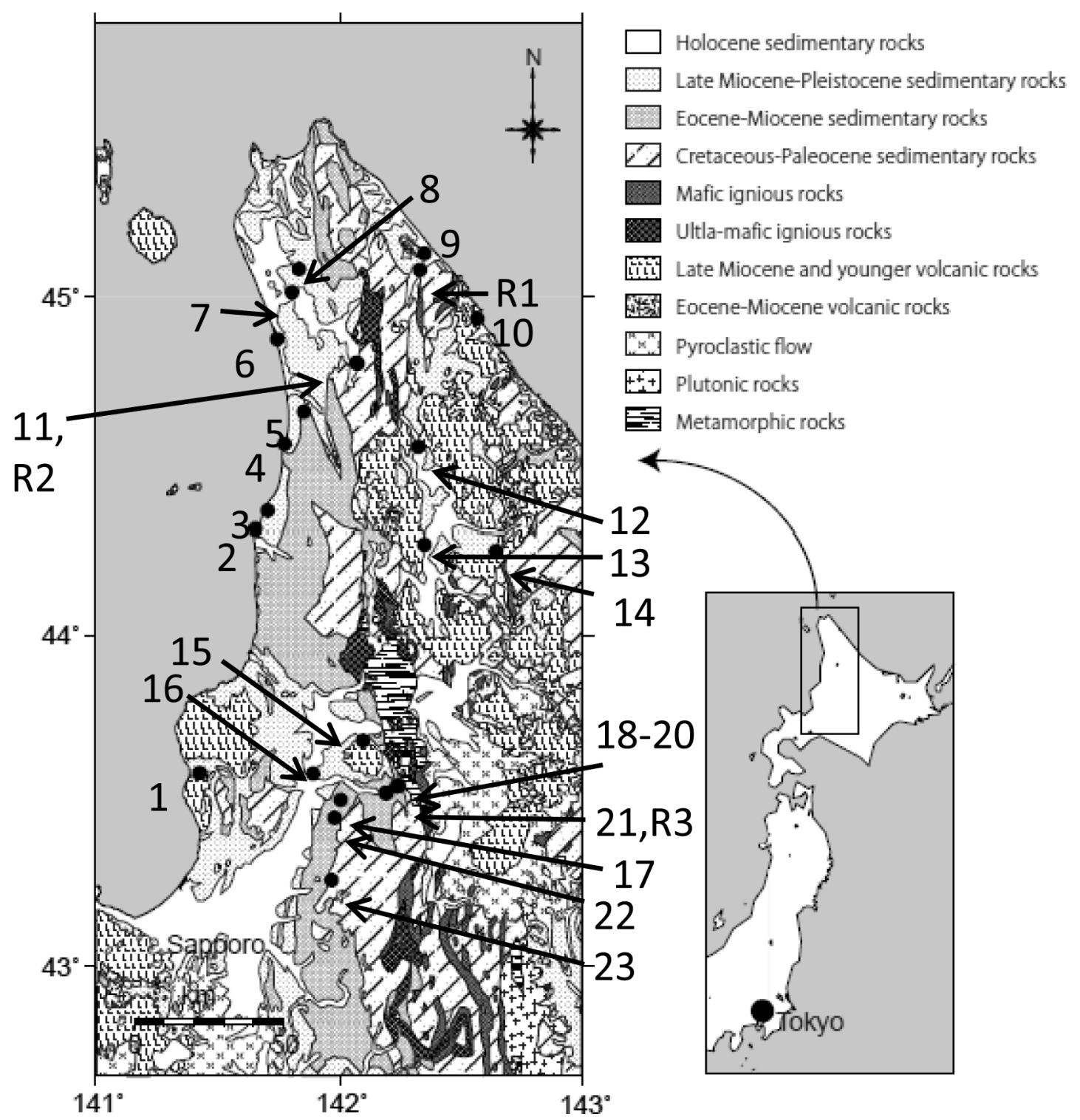

Fig. 1. Localities of water and gas sampled. Geological map was quoted from Geological Survey of Japan (2002). Sample numbers correspond to those in Tables 1 and 3.

local meteoric water and then undergone compositional changes during diagenesis. However, the detailed mechanism responsible for the apparent $\mathrm{D}$ enrichment and $\mathrm{Cl}$ depletion of the fluids are presently unclear. One possibility is that mixing occurred between connate water and water produced by dehydration. Possible candidate dehydration reactions during progressive burial are the transition from opal A to $\mathrm{C}$ and/or transformation of smectite to illite with or without heating.

In mud volcanoes, formations created by geo-excreted liquids and gases, overpressured multiphase pore fluids (water and dissolved gases, mainly methane) are also rec- ognized and are located mostly above strike-slip faults. The sediment is fluidized by rapid advection of pore fluids through the sedimentary mass along a conduit fault (Brown, 1990). Although chemical and isotopic studies of the expelled fluids are very scarce, this type of fluid might originate at least partly in dehydration in a subduction zone. The main dehydration process is thought to be a transition from smectite to illite similar to that for geopressured fluids observed in sedimentary basins (e.g., Shih, 1967; Sokolov et al., 1968; Valyaev et al., 1985; Dia et al., 1995, 1999; Bechtel et al., 2000).

$\mathrm{He}, \mathrm{Ne}$ and $\mathrm{Ar}$ isotopic ratios and concentrations of 
noble gases in groundwaters in Japan have been analyzed and give us the information of their origin and formation process (e.g., Sano and Wakita, 1985, 1988; Umeda et al., 2006; Sano and Nakajima, 2008; Morikawa et al., 2008). In the studied area, the $\mathrm{He}$ and $\mathrm{Ne}$ isotopic ratios were analyzed for groundwaters in Horonobe (Nagao et al., 2003) and three thermal waters in northern Hokkaido (Sano and Wakita, 1985). These results show that the $\mathrm{R} /$ $\mathrm{Ra}$ is less than 0.2 (where $\mathrm{R}$ and $\mathrm{Ra}$ are the sample and atmospheric ${ }^{3} \mathrm{He} /{ }^{4} \mathrm{He}$ ratios $\left(1.39 \times 10^{-6}\right)$, respectively) and the ${ }^{4} \mathrm{He} /{ }^{20} \mathrm{Ne}$ ratio of 1000 and that most of $\mathrm{He}$ and $\mathrm{Ne}$ are of deep origin.

The aim of the present study is to research the distribution of geopressured fluid with high $\delta \mathrm{D}$ and low $\mathrm{Cl}$ concentration near the Horonobe area, Hokkaido, and to compare the characteristics of these waters with their rare gas isotopic compositions as well as other published data.

\section{Outline of Geology at Sampling Sites}

The studied region is located in the northwestern Hokkaido (Fig. 1), which is divided by Mesozoic rocks into west and east zones (Geological Survey of Hokkaido, 1992). The west zone consists of late Jurassic to Cretaceous rocks, comprising of mainly greenstones, cherts, siliceous mudstones, and so on. This zone includes serpentine and mafic igneous rocks, which have been metamorphosed to form high-pressure metamorphic rocks. The east zone is mainly composed of homogeneous Cretaceous lithologies with fine-grained turbidite and melange facies. The Paleogene system is distributed in the western part of the Paleozoic-Mesozoic Group, and includes the main coal fields of Hokkaido, which are aligned from south to north. There are older volcanoes, which formed during the Pliocene-Middle Pleistocene and newer ones formed in the early Pleistocene-late Pleistocene. Large thickness of felsic pyroclastic flow deposits are distributed in the central Hokkaido area. Marine argillaceous sediments of Late Miocene age are widely distributed in the northern part of the central basin (Tempoku-Haboro). These sediments consist of diatomite, porcellanite and siliceous shale and are divided, in ascending order, into the Wakkanai and Koetoi Formations based on lithology; the former is composed mainly of hard shale, while the latter is mainly composed of diatomite and diatomaceous mudstone.

In the northern Hokkaido siliceous Neogene rocks are cut by the Omagari Fault and deformed by an anticline that began to grow between 2.2 and $1.0 \mathrm{Ma}$, possibly due to the beginning of active tectonism in and around this area (Ishii et al., 2006a). The Omagari Fault is surrounded by a fault zone, about $120 \mathrm{~m}$ wide, that consists mainly of the damage zone, and is relatively permeable. A magnetotelluric survey showed several high-resistivity zones, one of which corresponds to the Omagari Fault as inferred from reflection seismic surveys. The highresistivity zones are correlated with bodies of lowsalinity water, which suggests that meteoric water has infiltrated through the permeable Omagari Fault zone (Ishii et al., 2006b).

In Hokkaido, there are many occurrences of thermal water with a temperature of higher than $25^{\circ} \mathrm{C}$. These waters are mainly distributed within high heat flow zones corresponding to an extension of the Tohoku-Japan Arc in the western Hokkaido and to the southwestern end of the Kuril Arc in the central-eastern Hokkaido. These zones coincide, for the most part, with the distribution of Quaternary volcanoes. No active volcanoes occur in the studied area.

\section{Sample Collection and Analytical Procedures}

Details of sampling sites are provided in Table 1. Samples of water from near the coast (No. 1 to 10) were obtained from wells, with depths of 371 to $1807 \mathrm{~m}$. This region is widely underlain by marine argillaceous sediments of Late Miocene age, which consist of diatomite, porcellanite and siliceous shale. Almost all the waters from the wells occur in the sedimentary rocks. The other waters from inland were collected from hot springs, wells, and closed coal mines. In the area, pre-Tertiary sediments are present and locally contain coal-bearing strata.

In the present paper, water samples are grouped as thermal waters $\left(>25^{\circ} \mathrm{C}\right)$ and groundwaters $\left(<25^{\circ} \mathrm{C}\right)$ on the basis of the outlet temperature. The maximum temperature is $49.9^{\circ} \mathrm{C}$ in Sample No. 2 (Tomamae). Water samples were collected in plastic bottles (1 L volume) from 30th August to 2nd September 2004. The sampling points are shown in Table 1 and Fig. 1. Sampling bottles used for the noble gas study were made of a low Hepermeability glass containing $\mathrm{Pb}$. Each bottle had an internal volume of about $50 \mathrm{~cm}^{3}$ and high-vacuum stopcocks were attached to both ends. Water was introduced directly into each glass bottle from the sampled water source through plastic tubing to avoid air contamination. After through rinsing with flowing water, the stop-cocks were closed. At several sampling sites, as shown in Table 1 , we collected free gases that were separated from waters using the same type of glass bottle.

Dissolved ion concentrations were measured with conventional methods. The major anions $\mathrm{Cl}$ and $\mathrm{SO}_{4}$ in filtered water samples were analyzed with a Dionex DX120 ion chromatograph using an IonPac As14 column. Alkalinity was determined using standard titration with $\mathrm{HCl}$. Cations were analyzed with ICP-MS and ICP-AES at the Naka Energy Research Laboratory, Energy Project and Technology Center, Mitsubishi Materials Corpora- 


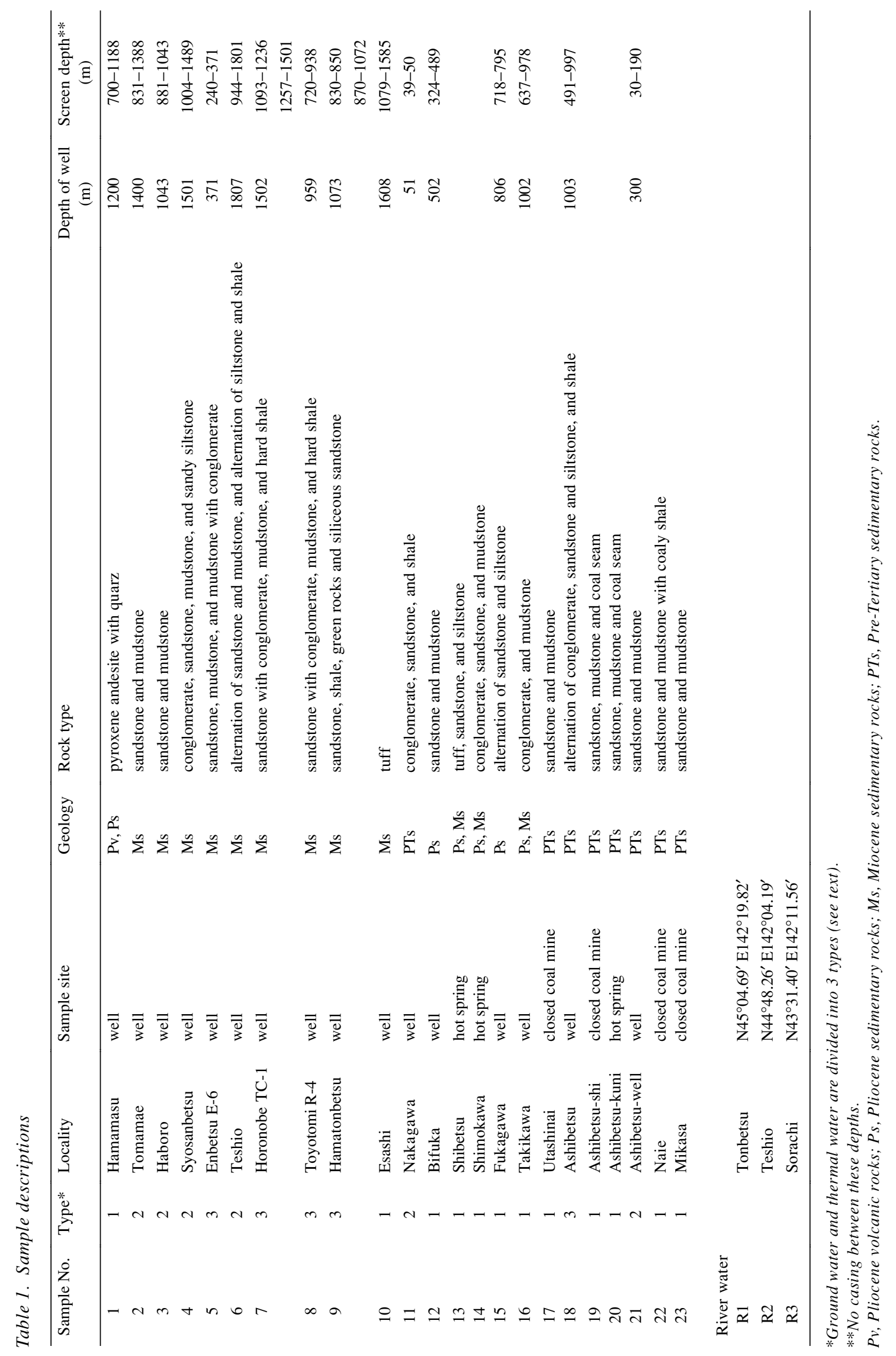


Table 2. Chemical and isotopic compositions of water samples. Sample numbers correspond to those in Fig. 1

\begin{tabular}{rrrrrrrrrrrr}
\hline Sample No. & Type* & $\begin{array}{c}\text { Temp. } \\
\left({ }^{\circ} \mathrm{C}\right)\end{array}$ & $\begin{array}{c}\mathrm{EC} \\
(\mathrm{S} / \mathrm{m})\end{array}$ & $\mathrm{pH}$ & $\begin{array}{c}\mathrm{ORP} \\
(\mathrm{mV})\end{array}$ & $\begin{array}{c}\mathrm{Na} \\
(\mathrm{mg} / \mathrm{L})\end{array}$ & $\begin{array}{c}\mathrm{K} \\
(\mathrm{mg} / \mathrm{L})\end{array}$ & $\begin{array}{c}\mathrm{Mg} \\
(\mathrm{mg} / \mathrm{L})\end{array}$ & $\begin{array}{c}\mathrm{Ca} \\
(\mathrm{mg} / \mathrm{L})\end{array}$ & $\begin{array}{c}\mathrm{NH}_{4} \\
(\mathrm{mg} / \mathrm{L})\end{array}$ & $\begin{array}{c}\mathrm{Cl} \\
(\mathrm{mg} / \mathrm{L})\end{array}$ \\
\hline 1 & 1 & 41.8 & 1.42 & 7.98 & -282 & 127 & 5 & 0 & 90 & 414 \\
2 & 2 & 49.9 & 4.69 & 7.00 & -218 & 10210 & 60 & 77 & 605 & 37 & 16770 \\
3 & 2 & 33.4 & 2.93 & 7.15 & -168 & 5810 & 104 & 176 & 805 & 34 & 11015 \\
4 & 2 & 24.5 & 2.39 & 7.63 & -178 & 5283 & 84 & 42 & 127 & 33 & 8295 \\
5 & 3 & 31.7 & 2.72 & 7.14 & -195 & 5550 & 38 & 28 & 663 & 17 & 9950 \\
6 & 2 & 33.3 & 4.86 & 7.30 & -118 & 11463 & 663 & 123 & 94 & 337 & 17527 \\
7 & 3 & 11.4 & 3.41 & 6.77 & -122 & 7415 & 235 & 117 & 153 & & 11022 \\
8 & 3 & 29.7 & 1.99 & 7.24 & -131 & 4455 & 32 & 30 & 79 & 46 & 6075 \\
9 & 3 & 46.4 & 0.95 & 7.92 & -140 & 2206 & 31 & 1 & 1 & 12 & 1906 \\
10 & 1 & 41.5 & 0.21 & 7.75 & 8 & 211 & 4 & 0 & 202 & 45 & 45 \\
11 & 2 & 28.2 & 4.69 & 7.23 & 207 & 8677 & 24 & 20 & 3347 & 25 & 19347 \\
12 & 1 & 20.5 & 0.09 & 8.05 & 15 & 190 & 4 & 2 & 12 & 179 \\
13 & 1 & 11.6 & 0.03 & 8.22 & 154 & 51 & 3 & 2 & 5 & 26 \\
14 & 1 & 14.2 & 0.18 & 6.14 & 33 & 207 & 21 & 108 & 75 & 1 & 117 \\
15 & 1 & 15.4 & 0.02 & 7.56 & -5 & 38 & 3 & 2 & 6 & 24 \\
16 & 1 & 30.3 & 0.19 & 7.33 & -176 & 290 & 13 & 19 & 60 & 3 & 463 \\
17 & 1 & 18.4 & 0.34 & 7.24 & -145 & 847 & 12 & 16 & 9 & 3 & 251 \\
18 & 3 & 15.8 & 2.54 & 7.00 & -122 & 5630 & 31 & 28 & 354 & 8 & 9020 \\
19 & 1 & 10.3 & 0.17 & 7.20 & -180 & 293 & 8 & 37 & 27 & 64 \\
20 & 1 & 13.2 & 0.40 & 7.16 & -175 & 897 & 11 & 25 & 25 & 3 & 476 \\
21 & 2 & 11.2 & 2.11 & 8.51 & -228 & 4910 & 25 & 24 & 40 & 9 & 7060 \\
22 & 1 & 11.7 & 0.12 & 7.85 & -158 & 278 & 5 & 13 & 5 & 1 & 8 \\
23 & 1 & 14.7 & 0.10 & 7.28 & -133 & 163 & 7 & 17 & 27 & 20 \\
\hline
\end{tabular}

\begin{tabular}{|c|c|c|c|c|c|c|c|c|c|c|c|}
\hline Sample No. & Type* & $\begin{array}{c}\mathrm{SO}_{4} \\
(\mathrm{mg} / \mathrm{L})\end{array}$ & $\begin{array}{c}\mathrm{HCO}_{3} \\
(\mathrm{mg} / \mathrm{L})\end{array}$ & $\begin{array}{c}\mathrm{F} \\
(\mathrm{mg} / \mathrm{L})\end{array}$ & $\begin{array}{c}\mathrm{Br} \\
(\mathrm{mg} / \mathrm{L})\end{array}$ & $\begin{array}{c}\mathrm{I} \\
(\mathrm{mg} / \mathrm{L})\end{array}$ & $\begin{array}{c}\mathrm{T}-\mathrm{Fe} \\
(\mathrm{mg} / \mathrm{L})\end{array}$ & $\begin{array}{c}\mathrm{SiO}_{2} \\
(\mathrm{mg} / \mathrm{L})\end{array}$ & $\begin{array}{c}\mathrm{Mn} \\
(\mathrm{mg} / \mathrm{L})\end{array}$ & $\begin{array}{c}\delta \mathrm{D} \\
(\% o)\end{array}$ & $\begin{array}{l}\delta^{18} \mathrm{O} \\
(\% \circ)\end{array}$ \\
\hline 1 & 1 & 27 & 27 & & 1 & & 0.01 & 31 & 0.01 & -68.2 & -10.8 \\
\hline 2 & 2 & 1 & 278 & & 33 & 27 & 5.80 & 33 & 0.39 & -23.0 & 1.9 \\
\hline 3 & 2 & 4 & 128 & 1.8 & 29 & 16 & 1.00 & 75 & 0.06 & -40.2 & -3.1 \\
\hline 4 & 2 & 3 & 521 & 0.4 & 28 & 10 & 5.80 & 52 & 0.19 & -35.1 & -1.7 \\
\hline 5 & 3 & 2 & 198 & 2.2 & 24 & 21 & 12 & 33 & 0.37 & -18.6 & 5.6 \\
\hline 6 & 2 & 2 & 3565 & & 153 & 79 & 1.20 & 75 & 0.03 & -14.2 & 2.1 \\
\hline 7 & 3 & 3 & 3721 & 0.2 & 81 & 25 & 1.20 & 69 & 0.01 & -23.4 & 4.7 \\
\hline 8 & 3 & 2 & 1943 & 1.0 & 17 & 13 & 0.71 & 22 & 0.01 & -23.4 & 3.1 \\
\hline 9 & 3 & 4 & 2519 & 12.1 & 6 & & 0.06 & 27 & 0.01 & -41.9 & -0.3 \\
\hline 10 & 1 & 981 & 26 & 4.2 & & & 0.05 & 23 & 0.01 & -82.1 & -12.5 \\
\hline 11 & 2 & 2 & 78 & 1.6 & 43 & 37 & 0.23 & 4 & 0.10 & -8.1 & 5.7 \\
\hline 12 & 1 & 1 & 206 & 1.4 & 0 & & 0.23 & 32 & 0.02 & -79.4 & -11.4 \\
\hline 13 & 1 & 3 & 105 & 0.1 & 0 & & 0.10 & 43 & 0.04 & -80.4 & -12.2 \\
\hline 14 & 1 & & 1129 & & & 0 & 1.80 & 82 & 0.01 & -84.5 & -12.2 \\
\hline 15 & 1 & 3 & 96 & & & & 0.07 & 61 & 0.01 & -80.0 & -12.3 \\
\hline 16 & 1 & 14 & 287 & 0.7 & 1 & & 0.08 & 87 & 0.13 & -82.3 & -11.8 \\
\hline 17 & 1 & 5 & 2050 & & & & 0.01 & 14 & 0.01 & -73.8 & -11.3 \\
\hline 18 & 3 & 3 & 766 & 4.2 & 7 & 16 & 13 & 15 & 0.09 & -21.4 & 5.3 \\
\hline 19 & 1 & 100 & 925 & 0.8 & & & 0.01 & 9 & 0.01 & -76.7 & -11.6 \\
\hline 20 & 1 & 147 & 1840 & 2.0 & & & 0.01 & 10 & 0.04 & -71.8 & -10.0 \\
\hline 21 & 2 & 3 & 985 & 1.8 & 16 & 8 & 0.51 & 15 & 0.01 & -64.8 & -5.5 \\
\hline 22 & 1 & 5 & 879 & 0.4 & & & 0.01 & 13 & 0.01 & -73.4 & -11.4 \\
\hline 23 & 1 & 7 & 666 & 0.3 & & & 0.01 & 11 & 0.01 & -70.4 & -11.1 \\
\hline
\end{tabular}

*Ground water and thermal water are divided into 3 types (see text). 

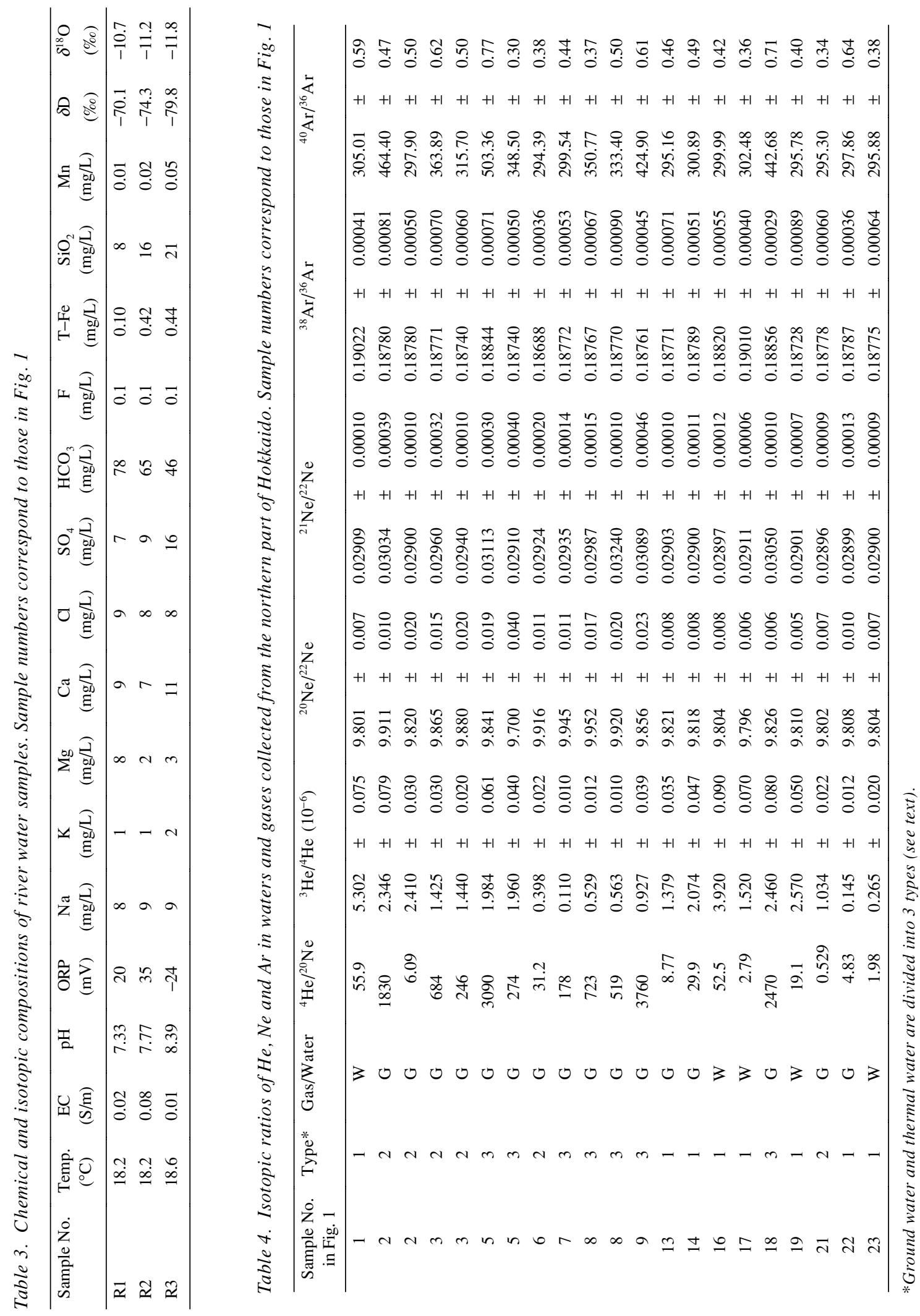


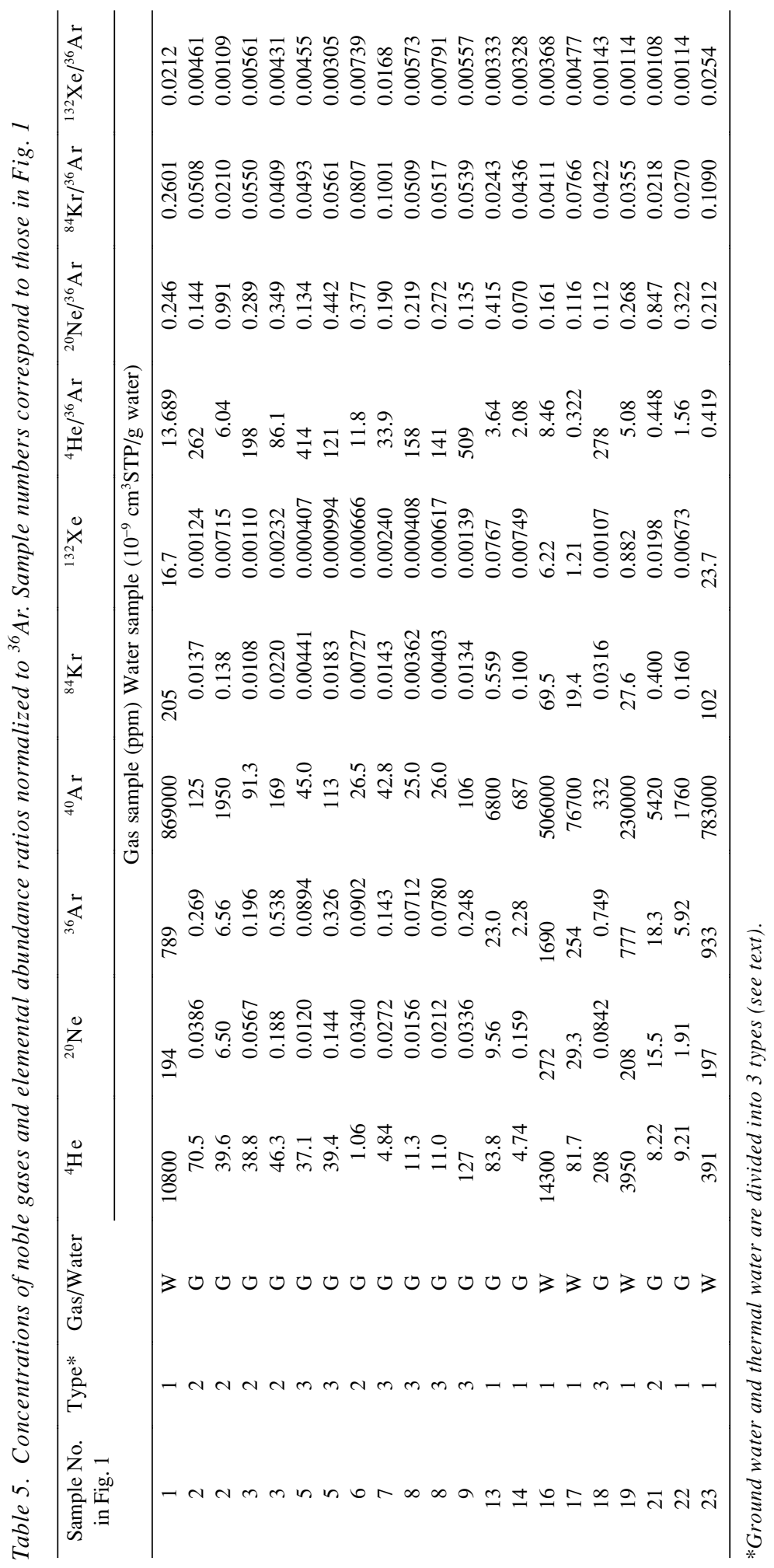


tion.

The $\mathrm{O}$ - and $\mathrm{H}$-isotopic measurements were performed at the Analytical Center, Mitsubishi Materials Techno Corporation. Oxygen isotope ratios were determined by the $\mathrm{CO}_{2}$ equilibration method (Epstein and Mayeda, 1953). The D isotopic values were determined by the method of Coleman et al. (1982). The $\delta^{18} \mathrm{O}$ and $\delta \mathrm{D}$ values are reported relative to V-SMOW with an analytical precision of $0.1 \%$ and $1 \%$, respectively.

Noble gas isotopic compositions and concentrations were measured in the Laboratory for Earthquake Chemistry, The University of Tokyo. Noble gases dissolved in the water samples were extracted using an all metal Toepler pump system. This system is basically the same as conventional ones made of glass (Steele, 1909; Dalton, 1935; Thielens and Malfait, 1965), but has been specially designed and constructed to measure water samples with low concentration of noble gases. A greatly reduced blank, especially for $\mathrm{He}$, is a great advantage of this metal Toepler pump compared to the conventional ones, which can allow atmospheric He to permeate into the vacuum line through glass. Dissolved gases were extracted from the water samples under vacuum and transferred into the noble gas purification line of a mass spectrometry system. Blank levels for the Toepler pump and the purification line were $1.2 \times 10^{-10}\left({ }^{4} \mathrm{He}\right), 3.0 \times 10^{-10}\left({ }^{20} \mathrm{Ne}\right), 3.3 \times$ $10^{-10}\left({ }^{36} \mathrm{Ar}\right), 9.8 \times 10^{-12}\left({ }^{84} \mathrm{Kr}\right)$ and $6.3 \times 10^{-13}\left({ }^{132} \mathrm{Xe}\right)$, all in units of $\mathrm{cm}^{3} \mathrm{STP}$. These blank levels are several orders of magnitude lower than the amounts of noble gases extracted from the water samples. The noble gases extracted from the water samples and those from the gas samples were purified by two Ti-Zr getters heated at about $800^{\circ} \mathrm{C}$ and separated into three fractions $\mathrm{He}, \mathrm{Ne}$ and $\mathrm{Ar}-$ $\mathrm{Kr}-\mathrm{Xe}$, i.e., $\mathrm{Ar}, \mathrm{Kr}$ and $\mathrm{Xe}$ were separated from $\mathrm{He}$ and $\mathrm{Ne}$ by adsorbing them on a charcoal trap cooled by liquid nitrogen. Then Ne was separated from He by adsorbing $\mathrm{Ne}$ onto a sintered stainless steel trap cryogenically cooled to a temperature of $15 \mathrm{~K}$.

The $\mathrm{He}, \mathrm{Ne}$ and Ar isotopic ratios and absolute abundances of all noble gases ( $\mathrm{He}, \mathrm{Ne}, \mathrm{Ar},{ }^{84} \mathrm{Kr}$ and ${ }^{132} \mathrm{Xe}$ ) were measured on a modified VG5400 (MS-III) noble gas mass spectrometer. Sensitivities and mass discrimination correction factors of the mass spectrometer system were determined by measuring known amounts of atmosphere with the same procedures that were applied for the samples. The discrimination factor for ${ }^{3} \mathrm{He} /{ }^{4} \mathrm{He}$ was determined by measuring the HESJ (He Standard of Japan) with ${ }^{3} \mathrm{He} /{ }^{4} \mathrm{He}=(28.88 \pm 0.14) \times 10^{-6}$ (Matsuda et al., 2002). Experimental uncertainties for the noble gas concentrations were estimated to be about $5-15 \%$, based on the reproducibility of measurements of the standard gas and ambiguity in the gas reduction procedure. Errors on the isotopic ratios in Table 4 are one standard deviation, including uncertainties for mass discrimination.

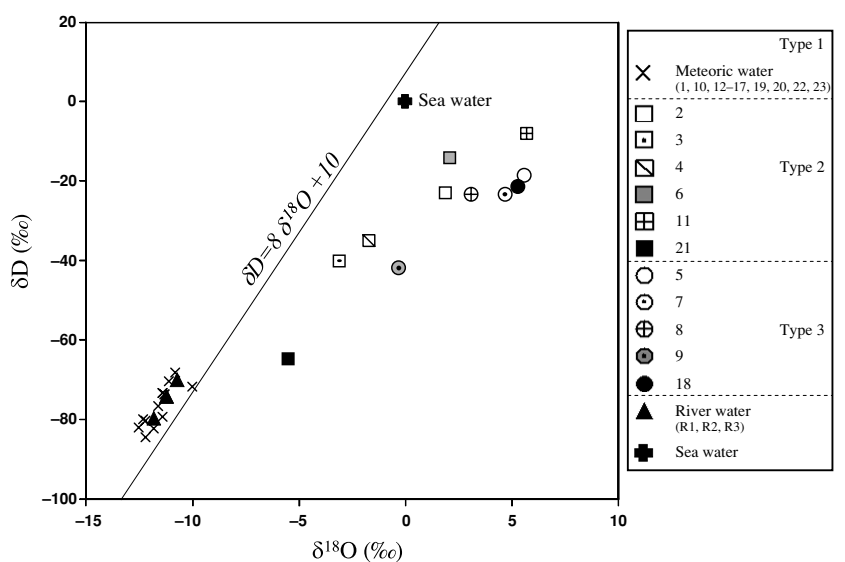

Fig. 2. $\delta D$ vs. $\delta^{18} O$ plots of water samples. The solid line is Meteoric Water Line defined by Craig (1961).

\section{RESULTS AND DISCUSSION}

The chemical and isotopic compositions of water samples are shown in Tables 2, 3, 4 and 5, where the sample numbers correspond to those in Figs. 1 through 10. The symbols (cross, circle and square) in these figures correspond to the three groups as discussed below.

\section{$\delta D$ and $\delta^{18} O$}

The $\delta \mathrm{D}$ and $\delta^{18} \mathrm{O}$ values of water samples are shown in Fig. 2. Half of the samples plot along the meteoric water line (e.g., Craig, 1961; Dansgaard, 1964) and are of meteoric origin (type 1, as shown by cross symbols). In contrast, the others have a good correlation between $\delta \mathrm{D}$ and $\delta^{18} \mathrm{O}$ values and may be a mixture of meteoric water and fossil sea water that is enriched in ${ }^{18} \mathrm{O}\left(\delta^{18} \mathrm{O}=c a .+6 \%\right)$. The $\delta \mathrm{D}-\mathrm{Cl}$ and $\delta^{18} \mathrm{O}-\mathrm{Cl}$ relationships (Fig. 3) show that some of the samples (type 2, square symbols) are plotting along and above the mixing lines between meteoric and fresh sea water, respectively. These results support the view mentioned above. In contrast, 5 samples (type 3 , circle symbols; No. 5, 7, 8, 9 and 18) are away from this mixing line. This means that these samples contain a 3 rd water component of different origin having a $\delta \mathrm{D}$ value of $c a .-20 \%$ and $\mathrm{Cl}$ concentration of $c a .6,000 \mathrm{mg} / \mathrm{L}$ as discussed below. Figure 3 also shows the $\delta^{18} \mathrm{O}-\mathrm{Cl}$ relationship which demonstrates that the type 3 waters have higher $\delta^{18} \mathrm{O}$ values than those of type 2 waters, which results from water-rock interaction under long residence time and/or high rock/water ratio.

Sample No. 8, one of the fluids having the characteristics of the 3rd component, was collected at Horonobe. More than 180 water samples from this site have been analyzed for their chemical and isotopic compositions as part of the Horonobe Underground Research Laboratory (Horonobe URL) project (e.g., Hama et al., 2007). Their 
(a)

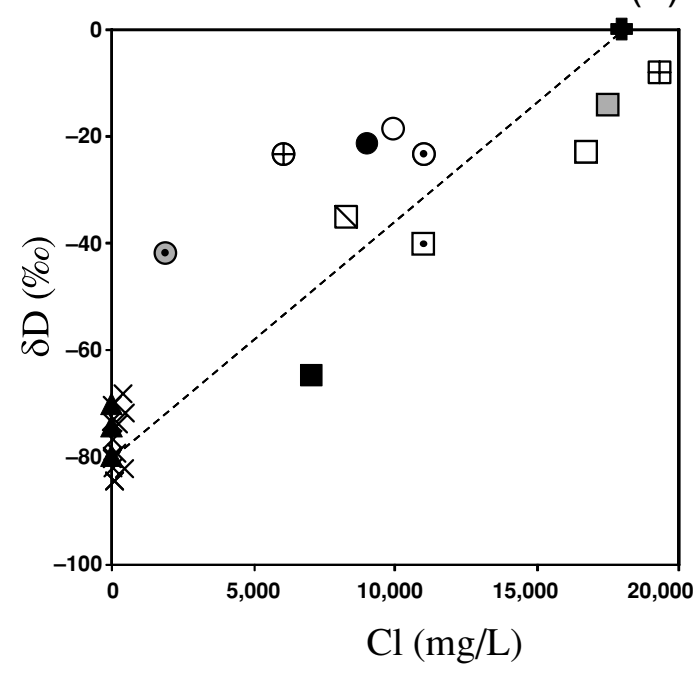

(b)

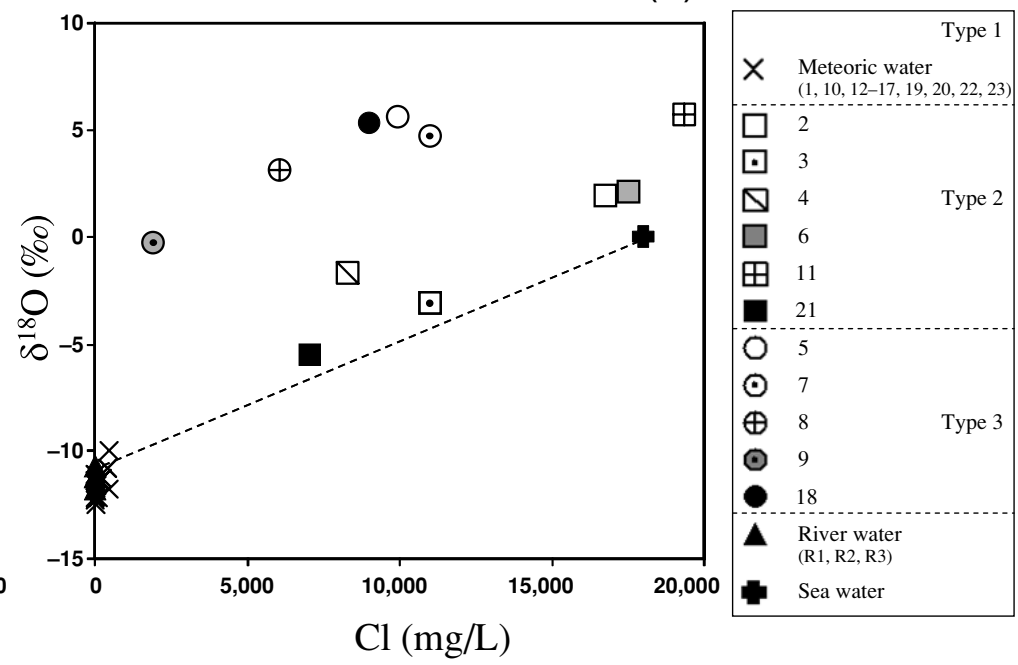

Fig. 3. (a) $\delta D$ vs. $\mathrm{Cl}$ and (b) $\delta^{I 8} \mathrm{O}$ vs. Cl diagrams.

results show that the groundwaters are divided into two types; $\mathrm{Na}-\mathrm{HCO}_{3}$ type water in the shallower part of the sedimentary formations and $\mathrm{Na}-\mathrm{Cl}$ type saline water in the deeper part of the sedimentary formations. Water-rock interactions and mixing are considered to be the dominant evolution processes of the groundwater. However, the $\mathrm{Na}-\mathrm{Cl}$ type waters have unusually high $\delta \mathrm{D}$ values and low $\mathrm{Cl}$ concentrations of -20 to $-30 \%$ and 5,000 to 6,000 $\mathrm{mg} / \mathrm{L}$, respectively (Ishii et al., 2006), similar to those of sample No. 8 in the present study. These results indicate that groundwater with a high proportion of the $3 \mathrm{rd}$ component is widely distributed in the deeper part of this area in the Wakkanai Formation. The enrichment factor $(\Delta \mathrm{D})$ is defined as the difference between $\delta \mathrm{D}$ that a sample would have if it originated by simple dilution of current sea water by local meteoric water (using the $\mathrm{Cl}$ content of the sample to estimate the degree of dilution), and the observed $\delta \mathrm{D}$ of the sample (Ishii et al., 2006). The $\Delta \mathrm{D}$ increases up to $45 \%$ at depths below $-500 \mathrm{~m}$, where opal A changes to opal CT. At this depth, the $\mathrm{H}_{2} \mathrm{O}^{+}$contents in the rocks decreases by $2 \mathrm{wt} \%$ (Ishii et al., 2006).

The groundwater and thermal water samples studied are divided into 3 groups on the basis of their isotopic and chemical compositions; type 1 (sample Nos. 1, 10, 12 to $17,19,20,22$ and 23) mostly of meteoric origin, type 2 (Nos. 2, 3, 4, 6, 11 and 21) which is a mixture of local meteoric water and fossil sea water, and type 3 (Nos. $5,7,8,9$ and 18) which is a mixture of meteoric water, fossil sea water and deep groundwater (geopressured fluid). There is no good correlation between their types and outlet temperatures. In Figs. 2 to 10, water samples of types 1, 2 and 3 are expressed by symbols of cross, circle and square, respectively. The geopressured (overpressured) fluid is defined as formation water with pressure between hydrostatic and lithostatic conditions, which is typically distributed below $c a .2 \mathrm{~km}$ depth in sedimentary rocks associated with oil and/or natural gas (e.g., Myers, 1968; Jones, 1970; Capuano, 1990, 1992; Oki et al., 1999; Xu et al., 2006).

\section{Chemical composition}

Concentrations of some major chemical constituents of water samples are plotted against $\mathrm{Cl}$ concentrations in Fig. 4. The broken line in the figure represents mixing between meteoric water and unmodified sea water. The $\mathrm{Na}$ concentrations of the water samples plot along this mixing line. The $\mathrm{K}, \mathrm{Mg}$ and $\mathrm{SO}_{4}$ plot lower than the line. These characteristics are independent of the temperature and are similar to those that have been reported for groundwaters from various localities around the world, such as in the Seikan tunnel in Japan (e.g., Mizukami et al., 1977), Frio Formation in U.S.A. (Land, 1995), and Aspo in Sweden (Laaksoharju, 1990; Laaksoharju et al., 2008). These studies have attributed the observed chemical characteristics to water-rock interaction and mixing processes. It is noted that the $\mathrm{HCO}_{3}$ concentrations are much higher than those of the mixing line in Fig. 4 and that samples with high $\mathrm{HCO}_{3}$ concentrations have low $\mathrm{Ca}$ concentrations. The saturation indices of water samples with respect to calcite were calculated from the observed chemical compositions in Table 2 by using the chemical modeling code, PHREEQ-C (Parkhurst and Appelo, 1999). The saturation indices (S.I.) are expressed as follows;

$$
\text { S.I. }=\log (\mathrm{Q} / \mathrm{K}) \text {, }
$$


(a)
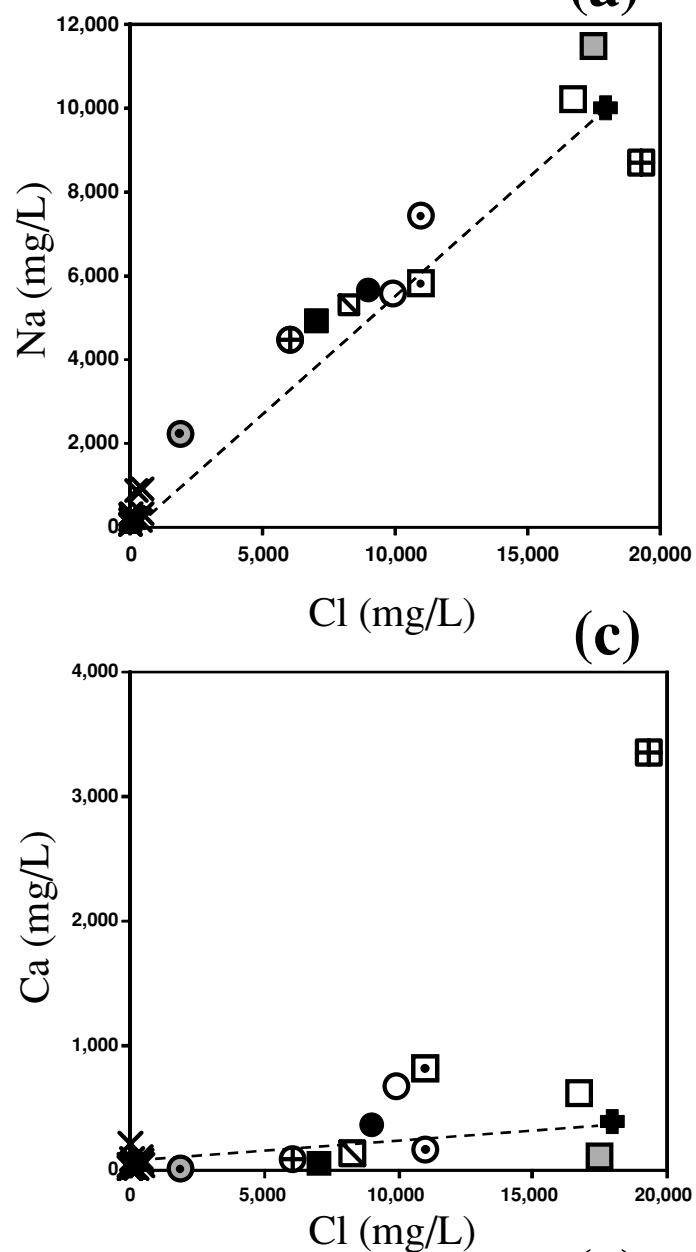

(e)

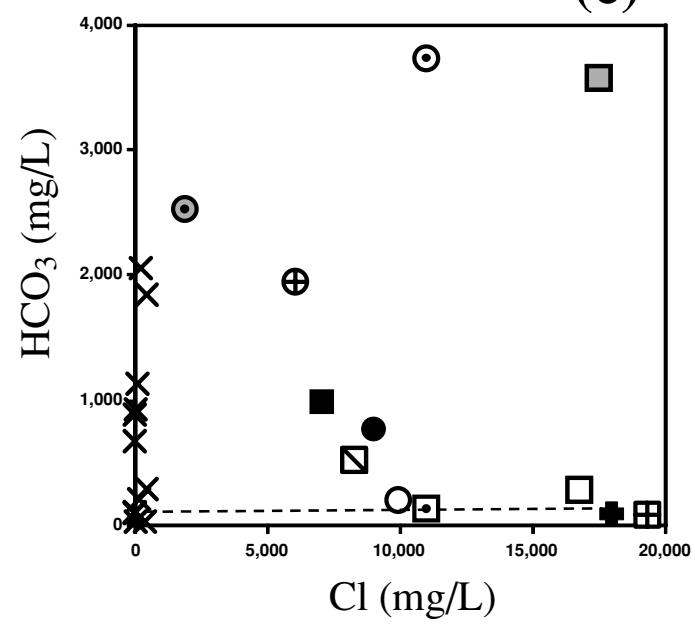

(b)
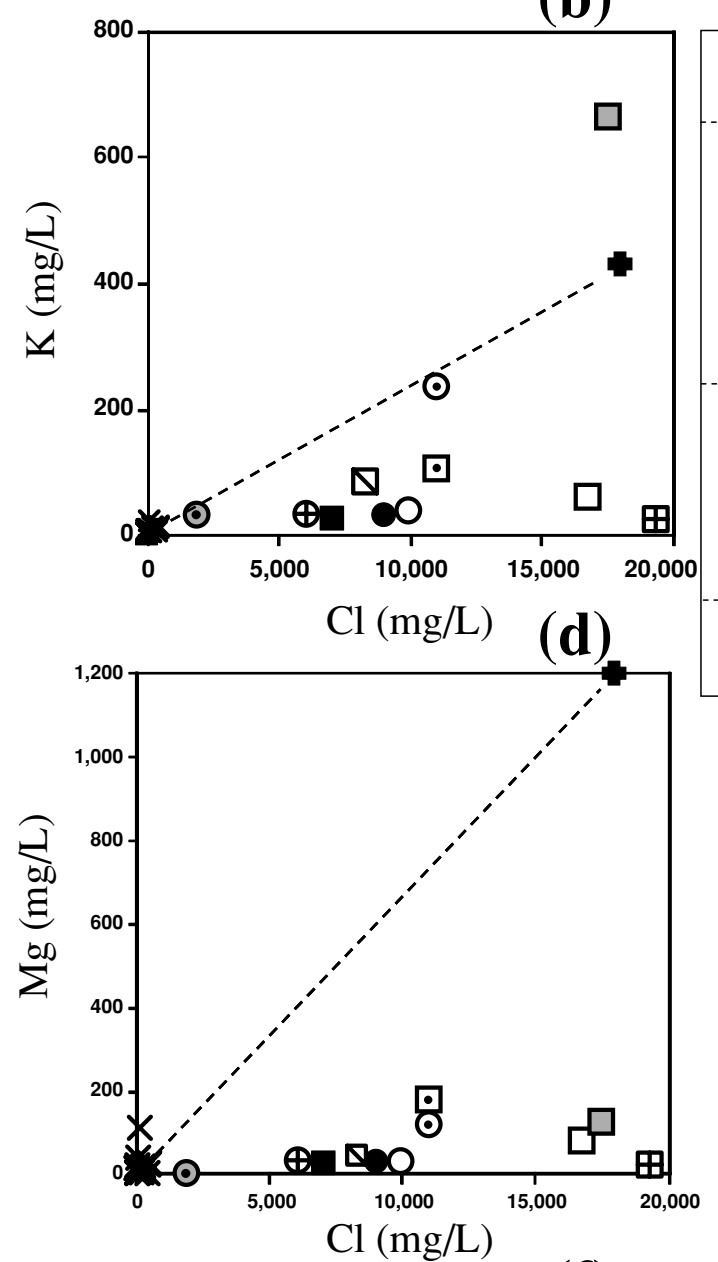

(f)

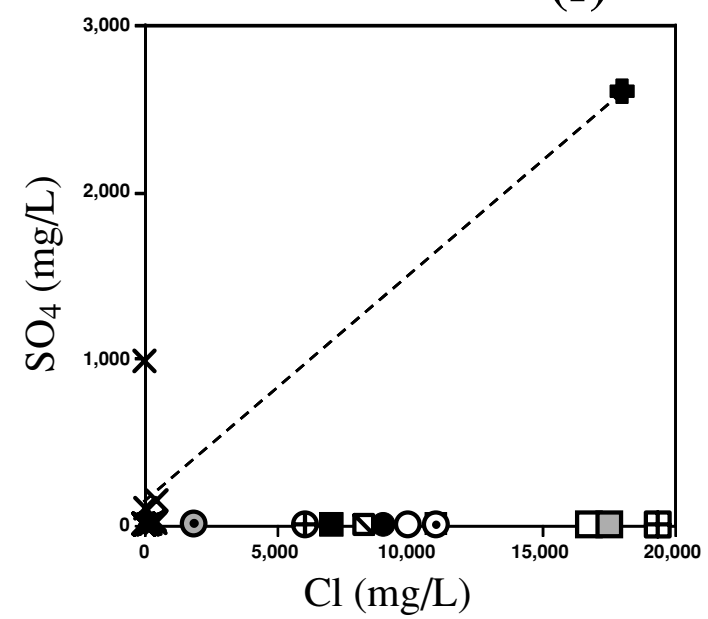

Fig. 4. Correlation diagrams for some chemical constituents plotted against Cl concentration. 


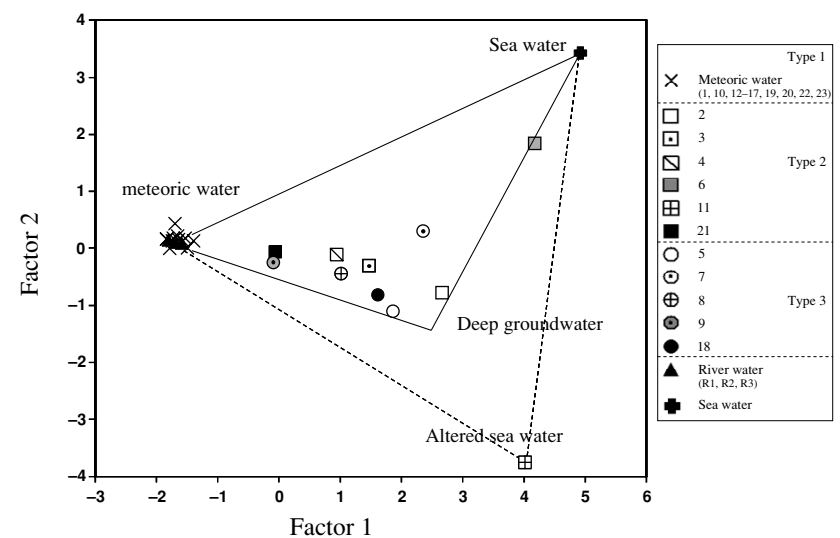

Fig. 5. M3 modelling of hydrogeochemical data for the northern Hokkaido area. The three end members are shown.

where $\mathrm{Q}$ and $\mathrm{K}$ are the activity product and solubility product for $\mathrm{Ca}^{2+}$ and $\mathrm{CO}_{3}{ }^{2-}$, respectively. The calculations show that most water samples are under-saturated (S.I. = $-1.74 \sim-0.13)$ with respect to calcite except for sample Nos. 6 (S.I. $=0.13$ ) and 21 (S.I. $=0.31)$. Sample No. 11 has the highest Ca concentration $(3,347 \mathrm{mg} / \mathrm{L})$ of all samples studied, where the $\mathrm{Cl}$ concentration $(19,347 \mathrm{mg} / \mathrm{L})$ is almost the same as that of unmodified sea water. The S.I. of calcite for this sample was -0.19 . Taking into account the fact that the solubility of calcite decreases with increasing temperature, most water samples studied are thought to have been saturated with respect to calcite, but become under-saturated due to decrease in temperature during their ascent to the surface. The temperatures at which the waters are saturated with respect to calcite are calculated to be 50 to $150^{\circ} \mathrm{C}$, which are higher than the observed temperature.

The chemical and isotopic compositions of the waters were subjected to multivariate statistical analysis using the code M3 (multivariate mixing and mass-balance calculations), as described in Laaksoharju et al. (1999a, b). This statistical analysis shows that the water samples studied look as a mixture of three end members of meteoric water, fresh sea water and altered sea water (corresponding to sample No. 11) (Fig. 5). In Fig. 5, the type 3 groundwaters (circle) are plotted in the middle field between these end members and can not be explained by mixing of meteoric water, fresh sea water and altered sea water. As mentioned before, the sample No. 8 has the highest $\Delta \mathrm{D}$ value and low $\mathrm{Cl}$ concentration among the type 3 waters (Fig. 3). These features may imply that sample No. 8 groundwater is another end member. According to these results, the type 1 groundwaters are of meteoric origin and the type 2 samples are mixtures of meteoric water, fresh sea water and fossil sea water enriched in ${ }^{18} \mathrm{O}$. The type 3 groundwaters are recognized to be mix-

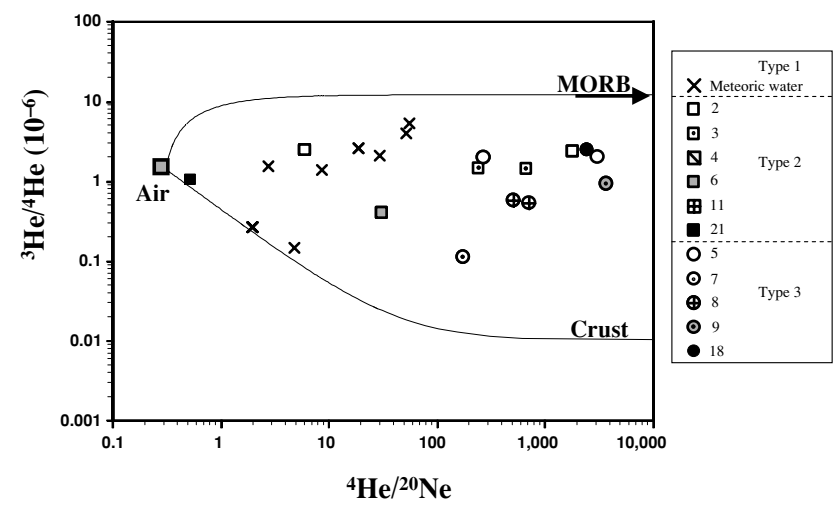

Fig. 6. ${ }^{3} \mathrm{He} /{ }^{4} \mathrm{He}$ vs. ${ }^{3} \mathrm{He} /{ }^{20} \mathrm{Ne}$ plot of water and gas samples. The solid curves show mixing lines between Air and MORB, and Air and Crust, respectively.

tures of geopressured fluid represented by sample No. 8 and meteoric water, fresh sea water and fossil sea water. Sample No. 11 has an unusual high Ca concentration (Fig. 4). Such Ca-rich waters are reported to occur in the submarine volcanogenic Kunnui formation about $200 \mathrm{~m}$ below the sea floor in the shafts of the Seikan Undersea Tunnel between Honshu and southern Hokkaido, between zero and $4 \mathrm{~km}$ off shore (Mizukami et al., 1977). The concentration of $\mathrm{Cl}$ of the waters was reported to range from 700 to $17,500 \mathrm{mg} / \mathrm{L}$, close to the concentration in seawater, whereas $\mathrm{Ca}$ concentration varies from 530 to $3100 \mathrm{mg} / \mathrm{L}$. In these samples, concentrations of $\mathrm{HCO}_{3}$ are lower than $60 \mathrm{mg} / \mathrm{L}$. The chemical characteristics of sample No. 11, i.e., high Ca concentration, low $\mathrm{HCO}_{3}$ concentration and $\mathrm{Cl}$ concentration close to that of sea water, are interpreted to indicate fossil sea water as reported elsewhere (e.g., Land, 1995).

\section{Rare gas isotopes}

Figure 6 shows a plot for ${ }^{3} \mathrm{He} /{ }^{4} \mathrm{He}$ versus ${ }^{4} \mathrm{He} /{ }^{20} \mathrm{Ne}$ ratios. All gas and dissolved gas samples except for Nos. 21, 22 and 23 gave medium values between the MORBAIR and CRUST-AIR mixing lines. There is no clear difference in ${ }^{3} \mathrm{He} /{ }^{4} \mathrm{He}$ ratios between all types. This means that these gases come from both magmatic and radiogenic sources, where the proportion of MORB component in the samples is calculated to be $c a$. $20 \%$, assuming that the MORB gas has a ${ }^{3} \mathrm{He} /{ }^{4} \mathrm{He}$ ratio of $11 \times 10^{-6}$ and that of CRUST gas of $1 \times 10^{-8}$. It is noted that the range of ${ }^{4} \mathrm{He} /{ }^{20} \mathrm{Ne}$ ratios of type 3 samples is higher than that of type 1, while that of type 2 overlaps with types 1 and 3 except for sample No. 21. Sample Nos. 21, 22 and 23 are plotted along the CRUST-AIR mixing lines and are of radiogenic origin. In all the samples, two samples 1 and 16 of type 1 have the highest ${ }^{3} \mathrm{He} /{ }^{4} \mathrm{He}$ ratios, suggesting a large contribution of magmatic gas. 


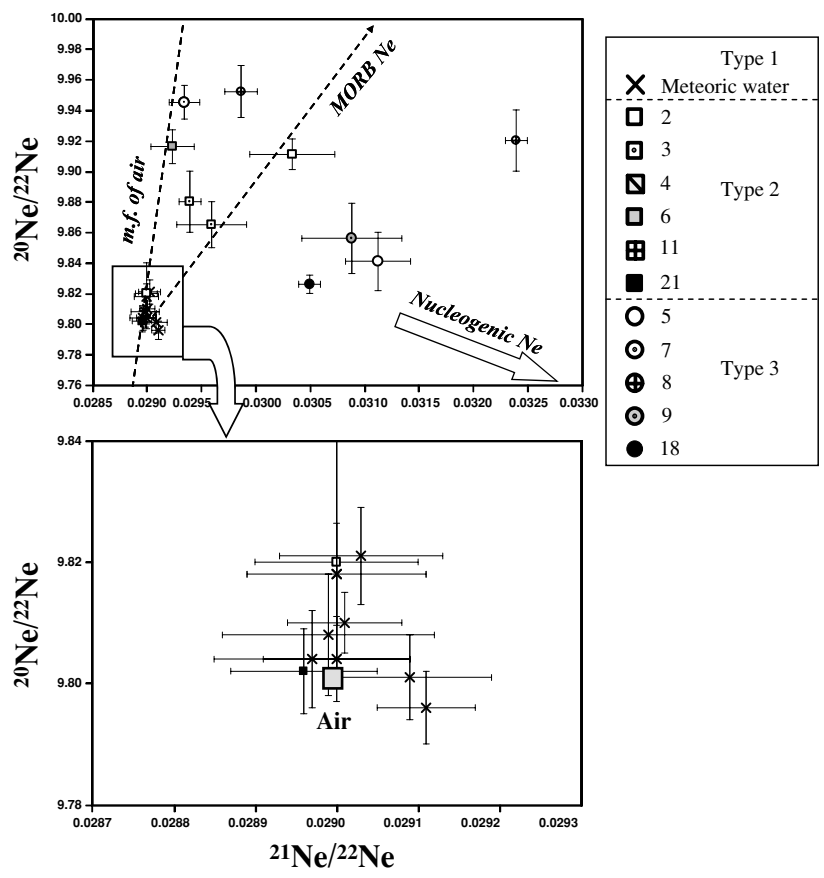

Fig. 7. ${ }^{3} \mathrm{He} /{ }^{4} \mathrm{He}$ vs. ${ }^{21} \mathrm{Ne} /{ }^{22} \mathrm{Ne}$ plot of water and gas samples.

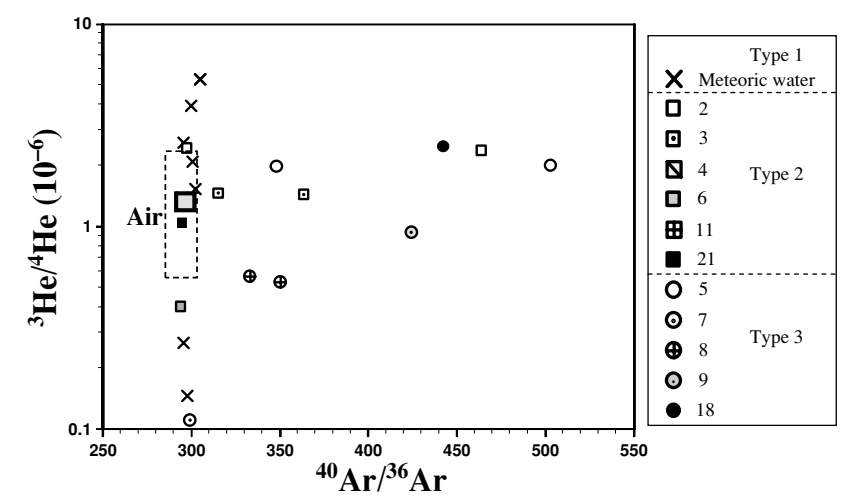

Fig. 8. ${ }^{3} \mathrm{He} /{ }^{4} \mathrm{He}$ vs. ${ }^{40} \mathrm{Ar} /{ }^{36} \mathrm{Ar}$ plot of water and gas samples. The rectangle drawn by broken lines shows the composition range of groundwaters in the Horoman area reported by Nagao et al. (2003).

Groundwater samples of type 1 are of meteoric origin as mentioned before and have both $\mathrm{He}$ and $\mathrm{Ne}$ from MORB and radiogenic components (Fig. 6). This means that deep sourced $\mathrm{He}$ and $\mathrm{Ne}$ are added in these samples because the concentrations of $\mathrm{He}$ and $\mathrm{Ne}$ in meteoric water is low and easily changed by the addition of other sourced $\mathrm{He}$ and $\mathrm{Ne}$.

It is noted that ${ }^{20} \mathrm{Ne} /{ }^{22} \mathrm{Ne}$ and ${ }^{21} \mathrm{Ne} /{ }^{22} \mathrm{Ne}$ ratios in samples of type 1 are plotted around air and those in the other types have increasing of ${ }^{21} \mathrm{Ne} /{ }^{22} \mathrm{Ne}$ ratios with decreasing of ${ }^{20} \mathrm{Ne} /{ }^{22} \mathrm{Ne}$ ratios (Fig. 7). This means that both of

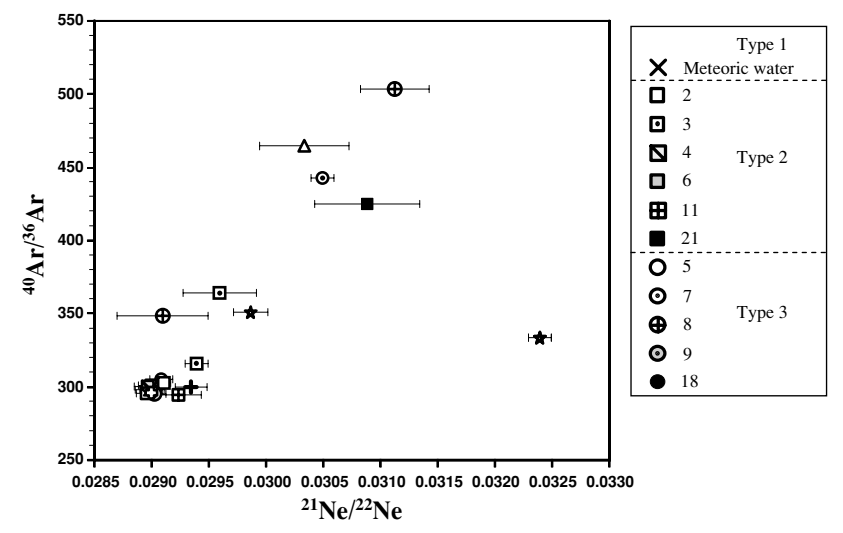

Fig. 9. ${ }^{40} \mathrm{Ar} /{ }^{36} \mathrm{Ar}$ vs. ${ }^{21} \mathrm{Ne} /{ }^{22} \mathrm{Ne}$ plot of water and gas samples.

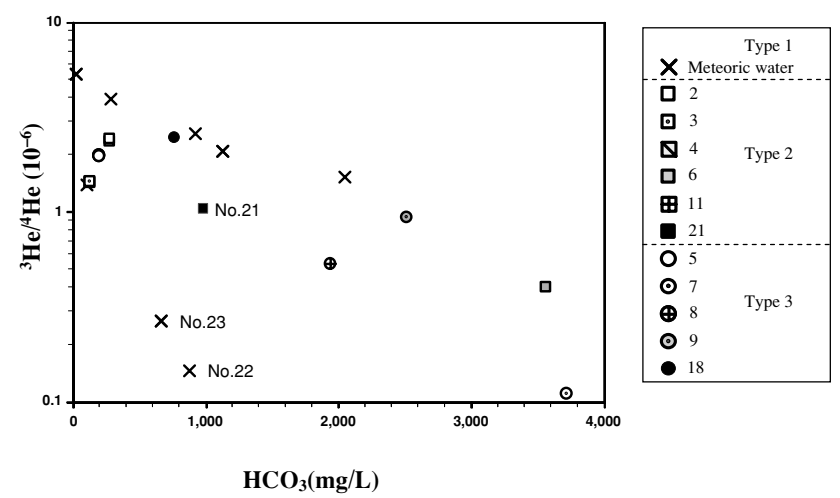

Fig. 10. ${ }^{3} \mathrm{He} /{ }^{4} \mathrm{He}$ vs. $\mathrm{HCO}_{3}$ concentration in water samples.

Ne from MORB and nucleogenic sources is added to types 1 and 2. Also noted is that type 1 samples have almost atmospheric ${ }^{40} \mathrm{Ar} /{ }^{36} \mathrm{Ar}$ value of 296 with variable ${ }^{3} \mathrm{He} /$ ${ }^{4} \mathrm{He}$ ratios (Fig. 8). This indicates that there is no contribution of nucleogenic Ar to these samples. In contrast, types 2 and 3 samples have higher ${ }^{40} \mathrm{Ar} /{ }^{36} \mathrm{Ar}$ ratios than the air value. Of the samples collected, the highest ${ }^{40} \mathrm{Ar} /$ ${ }^{36} \mathrm{Ar}$ ratios of about 500 were observed in sample No. 5 (type 3 groundwater). This means that the groundwaters are relatively older than type 1 waters. Nagao et al. (2003) reported ${ }^{3} \mathrm{He} /{ }^{4} \mathrm{He}$ and ${ }^{40} \mathrm{Ar} /{ }^{36} \mathrm{Ar}$ ratios (the rectangle drawn by broken lines in Fig. 8) of groundwaters collected from wells HDB 3 to 5 at 200 520 m depth in the Horonobe area to be 0.4 3.1 and 297 303, respectively. From the $\delta \mathrm{D}$ and $\delta^{18} \mathrm{O}$ values of pore water from cores in these wells, the waters are defined as types 1 and 2 as mentioned before (Teramoto et al., 2006; Hama et al., 2007). These results demonstrate that high ${ }^{40} \mathrm{Ar} /{ }^{36} \mathrm{Ar}$ ratios are not observed in the groundwaters at shallow depth ( $c a$. $500 \mathrm{~m}$ ) but observable in samples issuing from the fractures. A good correlation between ${ }^{40} \mathrm{Ar} /{ }^{36} \mathrm{Ar}$ and ${ }^{21} \mathrm{Ne} /{ }^{22} \mathrm{Ne}$ ratios is observed (Fig. 9) except for one of two No. 8 
samples. Note that this sample exhibited a high ${ }^{21} \mathrm{Ne} /{ }^{22} \mathrm{Ne}$ ratio away from the other samples (Fig. 7). In Fig. 9, type 1 samples plot around air. This demonstrates that types 2 and 3 samples are contributed by gases from nucleogenic sources.

Groundwaters and thermal waters are characterized by high $\mathrm{CO}_{2}$ concentrations as mentioned before. Figure 10 shows that $\mathrm{HCO}_{3}$ concentration (total dissolved $\mathrm{CO}_{2}$ such as $\mathrm{H}_{2} \mathrm{CO}_{3}, \mathrm{HCO}_{3}{ }^{-}$, and $\mathrm{CO}_{3}{ }^{2-}$ are converted as $\mathrm{HCO}_{3}$ ) in the water samples increases with decreasing ${ }^{3} \mathrm{He} /{ }^{4} \mathrm{He}$ ratios except for sample Nos. 21, 22 and 23 which have no MORB derived $\mathrm{He}$ and $\mathrm{Ne}$ and almost constant $\mathrm{CO}_{2}$ concentration. This result implies that the $\mathrm{CO}_{2}$ of types 2 and 3 samples might come from both deep sources and sediments because the $\mathrm{He}, \mathrm{Ne}$ and $\mathrm{Ar}$ isotopes indicate the addition of MORB and nucleogenic sources.

\section{Occurrence of geopressured fluid}

Geopressured (overpressured) fluid is defined as formation water with pressures between hydrostatic and lithostatic conditions as mentioned before. The $\delta \mathrm{D}$ and $\delta^{18} \mathrm{O}$ data generally show that most of the geopressured fluids can be explained as a mixture of fossil sea water and local meteoric water with an oxygen isotope shift due to rock-water interaction. Several formation waters from oil fields have high $\mathrm{Cl}$ concentrations (up to 10 times of that of sea water; e.g., Birkle et al., 2002) due to dissolution of salt deposits. Recently, geopressured fluids with unusually high $\delta \mathrm{D}(-20 \%)$ and low $\mathrm{Cl}$ concentration ( $c a$. $6,000 \mathrm{mg} / \mathrm{L}$ ) have been observed along faults in several localities in Japan, e.g., Niigata (Oki et al., 1999; Xu et al., 2006), Horonobe (Ishii et al., 2006), Mobara gas field (Maekawa et al., 2006), and Miyazaki (Ohsawa and Oh$\mathrm{i}$, personal comm.). Fluids in mud volcanoes in various part of the world also have such high $\delta \mathrm{D}(-20 \%)$ and low $\mathrm{Cl}$ concentrations (e.g., Dia et al., 1999).

Ishii et al. (2006) examined the isotopic and chemical compositions of formation waters in the Horonobe area, including sample No. 8 of the present study (Toyotomi Spa. associated with $\mathrm{CH}_{4}$ ). This sample (Table 1) is thought to be a geopressured fluid that has ascended through the Ohmagari fault. The feature indicating marine environments of the geological formations suggests that this fluid may have been formed by sea water which underwent changes in isotopic and chemical compositions during diagenesis. Ishii et al. (2006) discussed the possibility that the isotopic change from 0 to $-20 \%$ was caused by dehydration of opal A during the formation of opal $\mathrm{C}$ (2 wt \% water can be released). The $\mathrm{D} / \mathrm{H}$ fractionation factor between opal (amorphous silica) and water is $-145 \%$ and $-108 \%$ at $25^{\circ} \mathrm{C}$ and $50^{\circ} \mathrm{C}$, respectively (Faure et al., 2000). This mineralogical transition is observed in the sedimentary rocks at about $-500 \mathrm{~m}$ depth, while the temperature is not clear but generally around $50^{\circ} \mathrm{C}$ (Ishii et al., 2006). During transition of opal A to C, the $\delta \mathrm{D}$ value and $\mathrm{Cl}$ concentration of the connate water in the sedimentary rocks might be decreased due to dilution by dehydrated water from opal A. However, the observed isotopic and chemical compositions cannot be explained by this model because the total amount of water dehydrated from rocks is too small compared to that of the connate water due to the large porosity (35\%). At greater depths, transition of smectite to illite is commonly observed (e.g., Bruce, 1984; Colten-Bradley, 1987). During this transition, the $\delta \mathrm{D}$ value and $\mathrm{Cl}$ concentration of the connate water become lower due to dilution by dehydrated water from smectite which has lower $\delta \mathrm{D}$ values (D/H isotopic fractionation between smectite and water is about $-40 \%$ at $25^{\circ} \mathrm{C}$; Savin and Epstein, 1970; Lawrence and Taylor, 1971; Yeh and Epstein, 1978).

Primmer and Shaw (1991) analyzed the oxygen and hydrogen isotopic compositions of argillaceous rocks from a partly overpressured Tertiary sequence in an offshore well from the Texas Gulf Coast. They showed increasing illitization of illite-smectite rich formations with depth of burial and a general trend towards enrichment of $\mathrm{D}$ and depletion of ${ }^{18} \mathrm{O}$ with increasing illitization. By using $\mathrm{D}$ and $\mathrm{O}$ isotopic fractionation factors between smectite/illite-water (Yeh, 1980; Savin and Lee, 1988), they calculated the $\delta \mathrm{D}$ and $\delta^{18} \mathrm{O}$ values of water in equilibrium with illite-smectite to be -15 to $-40 \%$ and -1 to $+8 \%$, respectively, similar to those of sample No. 8 in the present study. Hyeong and Capuano (2004) reported that $\delta \mathrm{D}$ values of water and clay in the normally pressured (lithostatic) and geopressured sections are different. In the normally pressured section $(<2.6 \mathrm{~km}), \delta \mathrm{D}$ of water is constant $(-15 \%)$, while $\delta \mathrm{D}$ of clay increases linearly from -59 to $-43 \%$ with increasing depth. In contrast, in the geopressured section $\delta \mathrm{D}$ of water decreases linearly from -7 to $-26 \%$ with increasing depth, while $\delta \mathrm{D}$ of clay is nearly constant $(-36 \%$ ).

Yeh (1980) demonstrated membrane filtration as a fundamental process in depleting the deuterium content of the migrating fluid in sedimentary rocks. This effect would also deplete the ${ }^{18} \mathrm{O}$ content of the migrating fluid (Coplen and Hanshaw, 1973; Demir, 1988). Primmer and Shaw (1991) examined the membrane filtration for hydrogen isotope compositions of interlayer water and showed that the water giving rise to the overpressure is more enriched in ${ }^{18} \mathrm{O}$ than normally pressured pore water. They indicated that membrane filtration cannot satisfactorily explain the trends in the calculated isotopic composition of the water in the overpressured zones. According to these previous studies, the observed chemical and isotopic characteristics of waters with unusually high $\delta \mathrm{D}$ in this study may be explained by conversion (dehydration) of smectite to illite and isotopic equilibration between water and smectite/illite during diagenesis (e.g., 
Bechtel et al., 2000). The low $\mathrm{Cl}$ concentration may result from dilution by dehydration water.

\section{Conclusions}

$\mathrm{H}, \mathrm{O}$ and rare gas isotopic compositions were analyzed for groundwaters and thermal waters (maximum temperature is $49.9^{\circ} \mathrm{C}$ ) in northwestern Hokkaido, Japan. The water samples can be divided into 3 types; type 1 is of meteoric origin, type 2 is a mixture of meteoric water and altered sea water (fossil sea water) and type 3 is a mixture of meteoric waters, altered sea waters and geopressured water. The geopressured fluids have a $\delta \mathrm{D}$ value of $-20 \%$ and $\mathrm{Cl}$ concentration of $6,000 \mathrm{mg} / \mathrm{L}$ and are widely distributed in northwestern Hokkaido. The ${ }^{3} \mathrm{He} /$ ${ }^{4} \mathrm{He}$ ratios of $5.5 \times 10^{-7}$ with high ${ }^{3} \mathrm{He} /{ }^{20} \mathrm{Ne}$ ratio $(\sim 700)$ of type 3 samples indicate a crustal He input with a small amount of He derived from MORB source. In this paper, we could not confirm the occurrence of the geopressured fluids at depths and their geological environments. From the detailed study at Horonobe (sample No. 8), the geopressured fluids might have migrated along fractures from deep crustal source.

Acknowledgments-One of the authors (A.U.) expresses his thanks to the late Professor H. Sakai for his kind encouragements and critical suggestions in many cases of his research life.

The authors wish to thank to R. Metcalfe for his critical comments and polishing English of this manuscript. The authors wish to thank to the members of Mitsubishi Materials Corp. and Mitsubishi Materials Techno Corp. for their kind advices and cooperation during this study. Thanks also go to T. Maruoka for his assistance during sampling. Y. Kuroda helped us in chemical equilibrium calculations for water samples.

We like to thank Y. Matsuhisa and M. Kusakabe and the anonymous reviewer for their constructive comments to improve the whole manuscript.

\section{REFERENCES}

Bechtel, A., Shieh, Y. N., Elliott, W. C., Oszczepalski, S. and Hoernes, S. (2000) Mineralogy, crystallinity and stable isotopic composition of illitic clays within the Polish Zechstein basin: implications for the genesis of Kupferschiefer mineralization. Chem. Geol. 163, 189-205.

Birkle, P., Rosillo-Aragón, J. J., Portugal, E. and Fong-Aguilar, J. L. (2002) Evolution and origin of deep reservoir water at the Activo Luna oil field, Gulf of Mexico, Mexico. Am. Assoc. Petrol. Geol. Bull. 86, 457-484.

Brown, K. (1990) The nature and hydrogeologic significance of mud diapirs and diatremes for accretionary systems. $J$. Geophys. Res. 95, 8969-8982.

Bruce, C. H. (1984) Smectite dehydration-its relation to structural development and hydrocarbon accumulation in Northern Gulf of Mexico Basin. Bull. Am. Assoc. Petrol. Geol. 68, 673-683.
Capuano, R. M. (1990) Hydrochemical constraints on fluidmineral equilibria during compaction diagenesis of kerogenrich geopressured sediments. Geochim. Cosmochim. Acta 54, 1283-1299.

Capuano, R. M. (1992) The temperature dependence of hydrogen isotope fractionation between clay minerals and water: Evidence from a geopressured system. Geochim. Cosmochim. Acta 56, 2547-2554.

Coleman, M. L., Shepherd, T. J., Durham, J. J., Rouse, J. E. and Moore, G. R. (1982) Reduction of water with zinc for H-isotope analysis. Anal. Chem. 54, 993-995.

Colten-Bradley, V. A. (1987) Role of pressure in smectite dehydration-effects on geopressured and smectite to illite transformation. Am. Assoc. Petrol. Geol. Bull. 71, 14141427.

Coplen, T. B. and Hanshaw, B. B. (1973) Ultrafiltration by a compacted clay membrane I. Oxygen and hydrogen isotopic fractionation. Geochim. Cosmochim. Acta 37, 2295-2310.

Craig, H. (1961) Isotopic variations in meteoric waters. Science 133, 1702-1703.

Dalton, R. H. (1935) Extraction and analysis of gases from glass. J. Am. Chem. Soc. 57, 2150-2153.

Dansgaard, W. (1964) Stable isotopes in precipitation. Tellus 16, 436-438.

Demir, I. (1988) Studies of smectite membrane behaviour: electrokinetic, osmotic, and isotopic fractionation processes at elevated pressure. Geochim. Cosmochim. Acta 52, 727737.

Dia, A. N., Castrec, M., Boulegue, J. and Boudou, J. P. (1995) Major-trace-element, and $\mathrm{Sr}$ isotope constraints on fluids circulations in the accretionary complex of Barbados. Part I: fluid origin. Earth Planet. Sci. Lett. 134, 69-85.

Dia, A. N., Castrec-Rouele, M., Boulegue, J. and Comeau, P. (1999) Trinidad mud volcanoes: Where do the expelled fluids come from? Geochim. Cosmochim. Acta 63, 1023-1038.

Epstein, S. and Mayeda, T. (1953) Variation of $\mathrm{O}^{18}$ content of waters from natural sources. Geochim. Cosmochim. Acta $\mathbf{4}$, 213-224.

Faure, K., Matsuhisa, Y. and Fujimoto, K. (2000) Water in amorphous silica and the hydrogen isotopic fractionation. Rept. Geol. Surv. Japan 51, 206 (in Japanese).

Geological Survey of Hokkaido (1992) Geology of Hokkaido and Geological Resources Geoenvironment. Geological Survey of Hokkaido, 23 pp.

Geological Survey of Japan, AIST (2002) Geological map of Japan 1:2,000,000, 5th ed.

Hama, K., Kunimaru, T., Metcalfe, R. and Martin, A. J. (2007) The hydrogeochemistry of argillaceous rock formations at the Horonobe URL site, Japan. Phys. Chem. Earth 32, 170180.

Hattori, K. and Sakai, H. (1979) D/H ratios, origins, and evolution of the ore-forming fluids for the Neogene veins and Kuroko deposits of Japan. Econ. Geol. 74, 535-555.

Hyeong, K. and Capuano, R. M. (2004) Hydrogen isotope fractionation factor for mixed-layer illite/smectite at $60^{\circ}$ to $150^{\circ} \mathrm{C}$ : new data from the northeast Texas Gulf Coast. Geochim. Cosmochim. Acta 68, 1529-1543.

Ishii, E., Yasue, K., Ohira, H., Furusawa, A., Hasegawa, T. and Nakagawa, M. (2006a) Inception of anticline growth near 
the Omagari Fault, northern Hokkaido, Japan. J. Geol. Soc. Japan 112, 286-299.

Ishii, E., Yasue, K., Tanaka, T., Tsukui, R., Matsuo, K., Sugiyama, K. and Matsuo, S. (2006b) Three-dimensional distribution and hydrogeological properties of the Omagari Fault in the Horonobe area, northern Hokkaido, Japan. $J$. Geol. Soc. Japan 112, 301-314.

Ishii, T., Haginuma, M., Suzuki, K., Hama, K., Kunimaru, T., Kobori, K., Shimoda, S., Ueda, A. and Sugiyama, K. (2006) Groundwater evolution processes in the sedimentary formation at the Horonobe, northern Hokkaido, Japan. Geochim. Cosmochim. Acta 70, Supplement 1, A280.

Jones, P. H. (1970) Thermal resources of the northern Gulf of Mexico basin. UN Symposium on the Development and Utilization of Thermal Resources, Pisa. Proceedings Geothermics, Spec. Iss. 2 2, 14-26.

Laaksoharju, M. (1990) Measured and predicted groundwater chemistry at Aspo. SKB Progress Report, 25-90-13.

Laaksoharju, M., Skårman, C. and Skårman, E. (1999a) Multivariate mixing and mass balance calculations (M3)a new concept and computer program for decoding hydrochemical information. SKB Technical Report TS 0001, Svensk Kärnbränslehantering AB.

Laaksoharju, M., Skårman, C. and Skårman, E. (1999b) Multivariate Mixing and Mass-balance (M3) calculations, a new tool for decoding hydrogeochemical information. Appl. Geochem. 14, 861-871.

Laaksoharju, M., Smellie, J., Tullborg, E.-L., Gimeno, M., Molinero, J., Gurban, I. and Hallbeck, L. (2008) Hydrogeochemical evaluation and modelling performed within the Swedish site investigation programme. Appl. Geochem. 23, 1761-1795.

Land, L. S. (1995) Na-Ca-Cl saline formation waters, Frio Formation (Oligocene), south Texas, USA: Products of diagenesis. Geochim. Cosmochim. Acta 59, 2163-2174.

Lawrence, J. R. and Taylor, H. P., Jr. (1971) Deuterium and oxygen-18 correlation: Clay minerals and hydroxides in Quaternary soils compared to meteoric waters. Geochim. Cosmochim. Acta 35, 993-1003.

Maekawa, T., Igari, S. and Kaneko, N. (2006) Chemical and isotopic compositions of brines from dissolved-in-water type natural gas fields in Chiba, Japan. Geochem. J. 40, 475-484.

Matsuda, J., Matsumoto, T., Sumino, H., Nagao, K., Yamamoto, J., Miura, Y. N., Kaneoka, I., Takahata, N. and Sano, Y. (2002) The ${ }^{3} \mathrm{He} /{ }^{4} \mathrm{He}$ ratio of the new internal He standard of Japan (HESJ). Geochem. J. 36, 191-195.

Mizukami, M., Sakai, H. and Matsubaya, O. (1977) Na-Ca$\mathrm{Cl}-\mathrm{SO}_{4}$-type submarine formation waters at Seikanundersea-tunnel, Japan-chemical and isotopic documentation and its interpretation. Geochim. Cosmochim. Acta 41, 1201-1212.

Morikawa, N., Kazahaya, K., Masuda, H., Ohwada, M., Nakama, A., Nagao, K. and Sumino, H. (2008) Relationship between geological structure and helium isotopes in deep groundwater from the Osaka Basin: Application to deep groundwater hydrology. Geochem. J. 42, 61-74.

Myers, J. D. (1968) Differential pressures, a trapping mechanism in Gulf Coast oil and gas fields. Gulf Coast Assoc.
Geol. Soc. Trans. 18, 56-80.

Nagao, K., Ueda, A., Kamei, J., Goto, A., Kawamura, M., Iwatsuki, T. and Hama, K. (2003) Rare gas and Sr isotopic compositions of groundwaters from Tono and Horonobe areas. Abst. Mass Spectrom. Soc. Japan 2, 42.

Oki, Y., Xu, H., Ishizaka, N. and Kawauchi, K. (1999) Geopressured hydrothermal system associated with active faults and historical destructive earthquakes Hydrothermal waters in the Niigata Basin. Hot Spring Sci. 48, 163-81 (in Japanese).

Parkhurst, D. L. and Appelo, C. A. J. (1999) Users Guide to PHREEQC (Version 2)-A Computer Program for Speciation, Batch-Reaction, One-Dimensional Transport, and Inverse Geochemical Calculations. Water-Resources Investigations Report, U.S. Department of the Interior, U.S. Geological Survey, 99-4259.

Primmer, T. J. and Shaw, H. (1991) Variations in the 6D and $\delta^{18} \mathrm{O}$ compositions of illite-smectites in a partly overpressured Tertiary sequence from an offshore well, Texas Gulf Coast, USA. Mar. Petrol. Geol. 8, 225-231.

Sakai, H. and Matsubaya, O. (1974) Isotopic geochemistry of the thermal waters of Japan and its bearing on the Kuroko ore solution. Econ. Geol. 69, 974-991.

Sakai, H. and Matsubaya, O. (1976) Stable isotopic studies of Japanese thermal systems. Geothermics 5, 97124.

Sano, Y. and Nakajima, J. (2008) Geographical distribution of ${ }^{3} \mathrm{He} /{ }^{4} \mathrm{He}$ ratios and seismic tomography in Japan. Geochem. J. 42, 51-60.

Sano, Y. and Wakita, H. (1985) Geographical distribution of ${ }^{3} \mathrm{He} /{ }^{4} \mathrm{He}$ ratios in Japan: Implications for arc tectonics and incipient magmatsim. J. Geophys. Res. 90, 8729-8741.

Sano, Y. and Wakita, H. (1988) Helium isotope ratio and heat discharge rate in Hokkaido island, northeastern Japan. Geochem. J. 22, 293-303.

Savin, S. M. and Epstein, S. (1970) The oxygen and hydrogen isotope geochemistry of clay minerals. Geochim. Cosmochim. Acta 34, 25-42.

Savin, S. M. and Lee, M. (1988) Isotopic studies of phyllosilicates. Hydrous Phyllosilicates (exclusive of micas) (Bailey, S. W., ed.), Reviews in Mineralogy, Mineral Society of America 19, 189-223.

Shibata, T., Akita, F., Suzuki, T. and Takahashi, T. (2005) Thermal water resources in Sapporo city and its vicinity. Rep. Hokkaido Geol. Surv. 76, 79-82.

Shih, T. T. (1967) A survey of the active mud volcanoes in Taiwan and a study of their types and the character of the mud. Petrol. Geol. Taiwan 5, 259-311.

Sokolov, A. V., Buniat-Zade, Z. A., Goedekian, A. A. and Dadashev, F. G. (1968) The origin of mud volcanoes and the regularities of their powerful eruptions. Advances in Organic Geochemistry, 474-484, Pergamon.

Steele, B. D. (1909) An Automatic Toepler Pump, designed to collect the gas from the apparatus being exhausted. Proc. Phys. Soc. London 22, 326-332.

Teramoto, M., Shimada, J. and Kunimaru, T. (2006) Evidences of groundwater regime in impermeable rocks by stable isotopes in pore waters of drilled cores. J. Japan Soc. Eng. Geol. 47, 68-76 (in Japanese).

Thielens, G. J. and Malfait, L. (1965) An improved combined 
Toepler pump and gas microvolumetric device. J. Sci. Instrum. 42, 28-30.

Umeda, K., Ogawa, Y., Asamori, K. and Oikawa, T. (2006) Aqueous fluids derived from a subducting slab: Observed high ${ }^{3} \mathrm{He}$ emanation and conductive anomaly in a nonvolcanic region, Kii Peninsula southwest Japan. J. Volcan. Geotherm. Res. 149, 47-61.

Valyaev, B. M., Grinchenko, Y. I., Erokhin, V. E., Prokhorov, V. S. and Titkov, G. (1985) Isotopic composition of gases from mud volcanoes. Lithol. Mineral Resource 20, 61-75.
Xu, H. L., Shen, J. W. and Zhou, X. W. (2006) Geochemistry of geopressured hydrothermal waters in the Niigata Sedimentary Basin, Japan. Island Arc 15, 199-209.

Yeh, H. W. (1980) D/H ratios and late stage dehydration of shales during burial. Geochim. Cosmochim. Acta 44, 341352.

Yeh, H. W. and Epstein, S. (1978) Hydrogen isotope exchange between clay minerals and sea water. Geochim. Cosmochim. Acta 42, 140-143. 